Case report

\title{
Fatal cranial injury in an individual from Messina (Sicily) during the times of the Roman Empire
}

\author{
Andrea Dario Messina, Ph.D, Anthropologist*, Giuseppe Carotenuto, MD, Physician, \\ Roberto Miccichè, BA, Anthropologist, Luca Sìneo, Ph.D., Professor of Anthropology \\ Dipartimento di “Scienze e Tecnologie biologiche, chimiche e farmaceutiche" LabHomo, Laboratori di Antropologia, Universita' di Palermo (I), Via Archirafi, \\ 18, 90123, Italy
}

\section{A R T I C L E I N F O}

\section{Article history:}

Received 4 January 2013

Received in revised form

25 July 2013

Accepted 25 September 2013

Available online 5 October 2013

\section{Keywords:}

Forensic sciences

Forensic anthropology

Cranial trauma

Perimortem lesion

Epidural hematoma

Roman Empire

\begin{abstract}
A B S T R A C T
Forensic and archaeological examinations of human skeletons can provide us with evidence of violence. In this paper, we present the patterns of two cranial lesions found on an adult male (T173) buried in a grave in the necropolis 'Isolato 96', Messina, Sicily, dating back to the Roman Empire (1st century BC - 1st century $\mathrm{AD}$ ). The skull reveals two perimortem traumatic lesions, one produced by a sharp object on the right parietal bone and the other one on the left parietal bone, presumably the result of a fall. The interpretation of fracture patterns found in this cranium are an illustration of how forensic approaches can be applied with great benefit to archaeological specimens.
\end{abstract}

(c) 2013 Elsevier Ltd and Faculty of Forensic and Legal Medicine. All rights reserved.

\section{Introduction}

During the research project 'From Zancle to Messana', which covered the history of Messina from its Greek foundations to Roman domination, archaeological explorations concentrated upon necropolis 'Isolato 96'. The excavations, supervised by the Sovrintendenza di Messina, which began in 1998 and were completed in 1999, have uncovered a wealth of archaeological finds. Stratigraphic information, together with the analysis of burial apparatus and funerary objects, have allowed the identification of different chronological stages which embrace an extensive period of time, from the Hellenistic era to Late Antiquity (4th century BC -5 th century AD). Especially during Roman Imperial period Messana seems to be characterized by strong social and institutional crises ${ }^{1}$ and radical changes in the arrangement of space for burials. ${ }^{2}$ Traditional sources for evidence of interpersonal violence and warfare in historical times are comprised documents and archaeological finds, including human remains. Usually, evidence of skeletal trauma cited in archaeological literature is primarily based on observations of the bone healing processes and remodeling,

\footnotetext{
* Corresponding author. Tel.: +39 (0)9123891806.

E-mail address: andreamess@gmail.com (A.D. Messina).
}

with little attention given to perimortem injuries. ${ }^{3}$ Indeed, when a trauma pattern has been observed in either forensic or archaeological settings, the following step would be to evaluate the timing of this injury and its possible association with the cause and manner of death. ${ }^{4}$

The cranium is often subjected to weapon-related trauma and injury patterns can be very complicated and difficult to evaluate. Moreover, cranial trauma can be caused by daily activities, as well as by all sorts of accidents. ${ }^{5-7}$ Several recent studies have addressed type and position of cranial traumatic injuries in relation to episodes of violence. ${ }^{8-18}$

This paper describes two cranial injuries observed in individual T173, which date to the Roman Empire (1st century BC-1st century AD), based on grave goods (Piriform Unguentarium) recovered in the grave. $^{2}$

For examining skeletal trauma we analyze the affected area according to the following traditional categories: fracture angle and outline, color and surface morphology.$^{19-21}$ Moreover, we applied 3D CT imaging to obtain additional features for distinguishing perimortem trauma and postmortem damage: preponderant texture, preponderant outline, relationship to the path of least resistance, signs of plastic response and the presence of hinging. ${ }^{22}$ Indeed, non-invasive imaging techniques are of great value in 


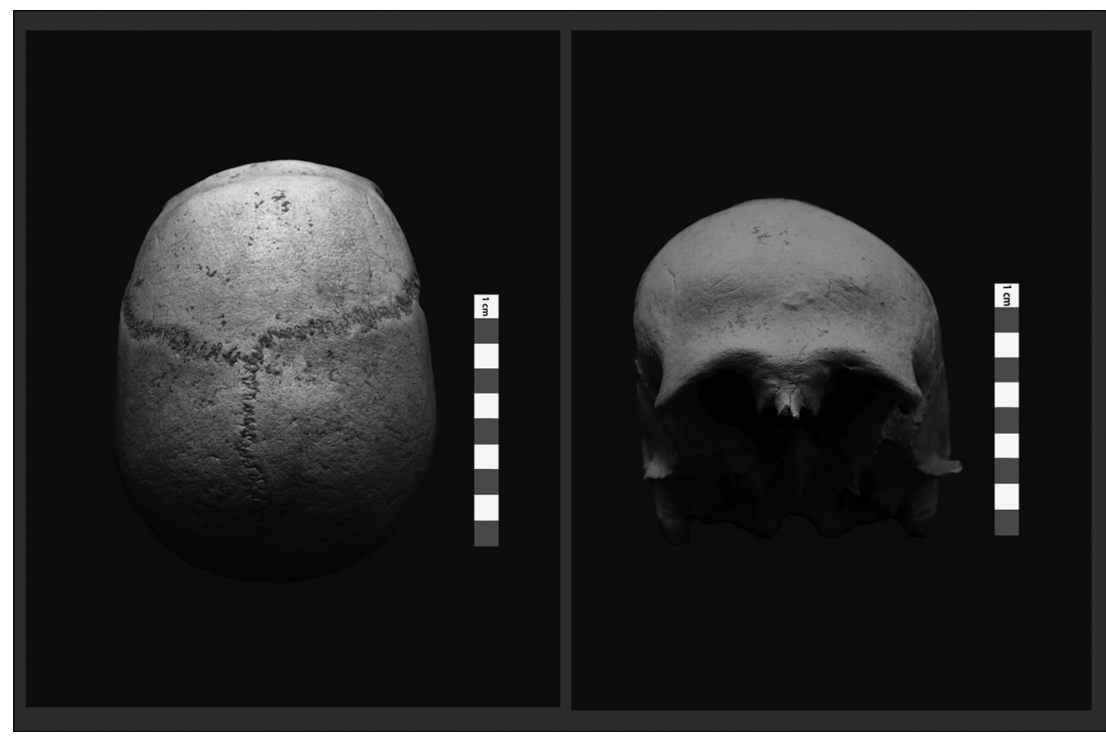

Fig. 1. Frontal and superior view of T173 skull.

forensic anthropology when applied to lesions with doubtful perimortem or postmortem features. ${ }^{23}$

The cranial lesions in T173 do not appear to indicate postdepositional alterations. Our own anthropological examination of the skull suggest that the lesions are of traumatic nature and were inflicted perimortem: the first trauma on the right parietal bone was caused by a sharp object, while the second, on the left parietal bone, could be the consequence of a fall.

The aim of this study was to examine these lesions with regard to their possible etiology and to formulate a hypotheses about the events that led to their occurrence, to establish whether these were, in fact, the cause of death of individual T173.

\section{Materials and methods}

The skull, labeled T173, derives from a complete inhumation burial.

Age estimation was based on pubic symphyseal face morphology ${ }^{24}$; metamorphosis at the sternal rib end ${ }^{25}$; morphology of auricular surface of the ilium. ${ }^{26}$ Sex was assigned via standard metric analysis of the pelvic bone traits. ${ }^{27}$ The following measurements have been taken: PUM, SPU, DCOX, IIMT, ISMM, SCOX, SS, SA, SIS and VEAC.

For the description of cranial fractures, we referred to the current criteria. ${ }^{3,28-30}$ In addition, we performed a CT scanning of the skull, using a multi detector scanner General Electric LightSpeed VCT 64 Slice CT, gantry rotation time $0.6 \mathrm{~s}$, slice thickness $0.6 \mathrm{~mm}$, high-resolution protocol, integrated with MIP and VRT-3D reconstruction. Data were saved as Digital Imaging and Commutations in Medicine format bitmap files (DICOM), which were later converted into High Dynamic Range image format files through the use of the software AMIRA 5.0..$^{31,32}$

Questions related to the weapon used were approached using techniques developed in forensic pathology and anthropology ${ }^{33-}$ 35; we also compared our results with sources of literature on the Mediterranean area in the Roman and Modern Ages. ${ }^{36-38}$

\section{Results}

The osteological parameters of the skeleton of individual T173 indicate a young adult (20-34 years).
All measurements detected from the T173 coxal bones unequivocally supported the assignation of male (with a $99.78 \%$ and 99.75\% posterior probabilities, for left and right sides respectively).

The skull is almost complete and appears to be asymmetric, due to a light depression of the left parietal bone (Fig. 1).

All mandibular teeth are present, except for the left M1 and M3 which were lost postmortem; the maxillary central incisors, the right lateral incisor, the right P4 and M1 were lost antemortem, while right P3 was lost postmortem.

On the external surface of the right parietal bone, near the coronal suture, an oval-shaped lesion is present bounded above by the temporal lines: the minor diameter measures $11 \mathrm{~mm}$ (a), while the major diameter measures $21 \mathrm{~mm}(\mathrm{~A})$. In this area there is a perforation (Fig. 2), shaped like a rectangular trapezoid, whit the following measurements: minor base (b) $3.93 \mathrm{~mm}$, major base (B) $6.0 \mathrm{~mm}$, oblique side $(l) 5.55 \mathrm{~mm}$, while the height $(h)$ measures $11 \mathrm{~mm}$ (Fig. 3). The perforation is delimited by bone fragments, introflexed but still attached to the surrounding bone and visible on the cerebral surface (Fig. 4). There are no signs of bony remodeling. On the endocranial surface the perforation affects some of the grooves of the right middle meningeal vessels.

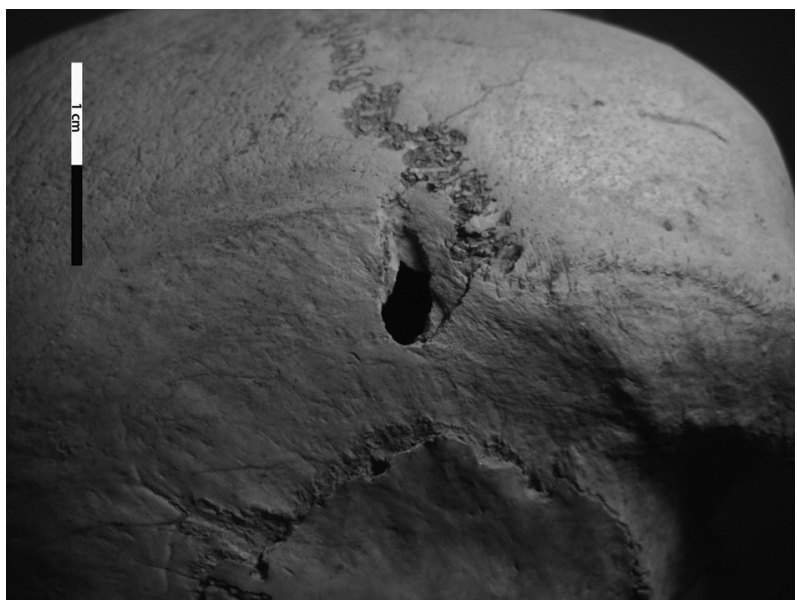

Fig. 2. Lateral view of T173 skull. Trauma on right parietal is visible. 


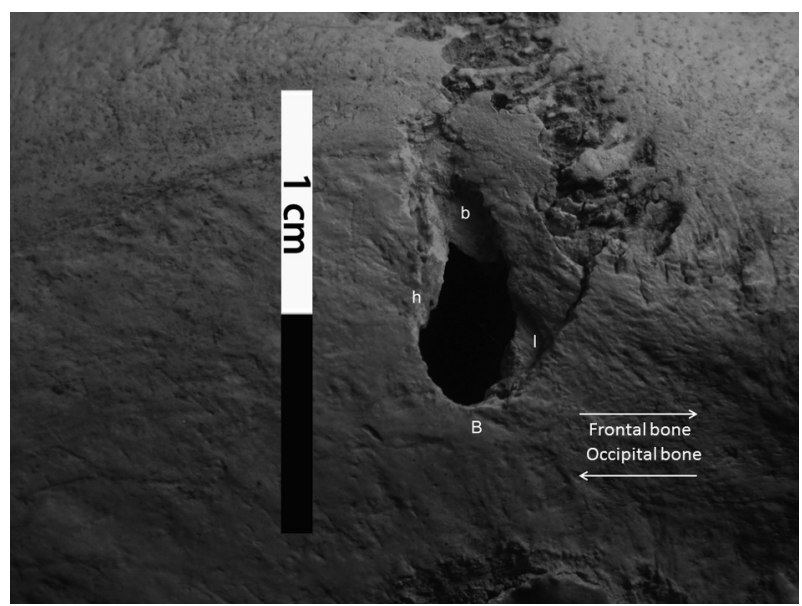

Fig. 3. T173: margins of the perforation on the ectocranial surface.

Another lesion is evident on the left parietal bone, near the lambda, above the hat brim line (HBL - Fig. 5). Three fracture lines radiate from this point. Two of the fracture lines involve only the outer table (Fig. 6): one fracture line extends into the lambdoidal suture for $58.75 \mathrm{~mm}$ and the other one into the occipital bone for $24.38 \mathrm{~mm}$. The third fracture line involves both cranial tables and extends along the left parietal bone for $78.17 \mathrm{~mm}$, with a fissure variable between 1.70 and $1.29 \mathrm{~mm}$. The edges of the fractures have the same color as the rest of the skull.

\section{Discussion}

Recognition and interpretation of bone trauma are essential components of bioarchaeology and forensic anthropology studies. ${ }^{3}$

Skeletal injuries can be caused by either intentional or nonintentional events, and are interpreted as antemortem, perimortem or postmortem. ${ }^{39-41}$

Perimortem injuries are those that occur at or near the time of death and are distinguished by an absence of any evidence of

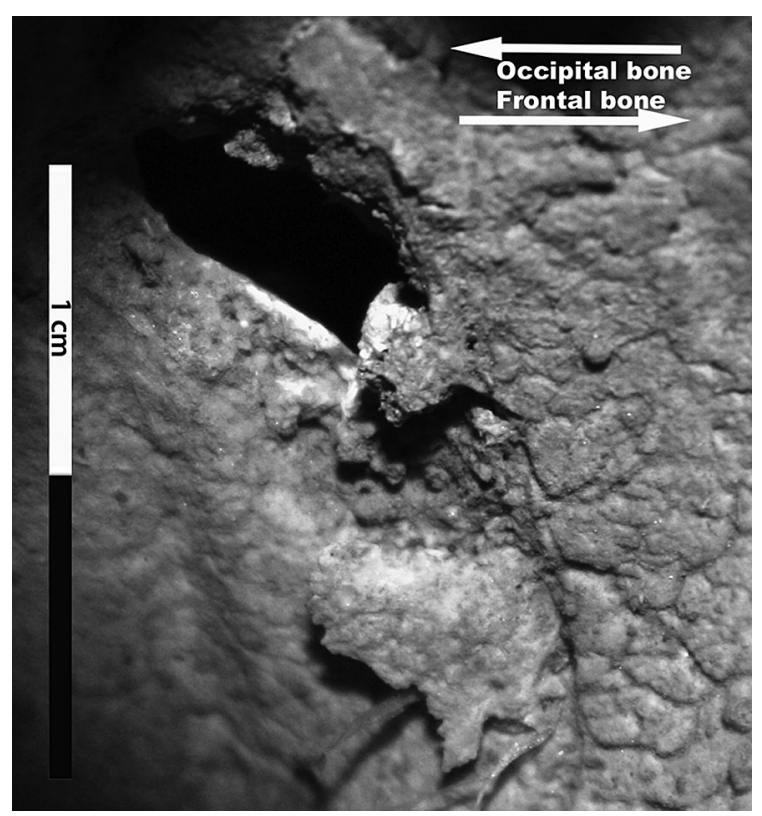

Fig. 4. T173: margins of the perforation on the endocranial surface.

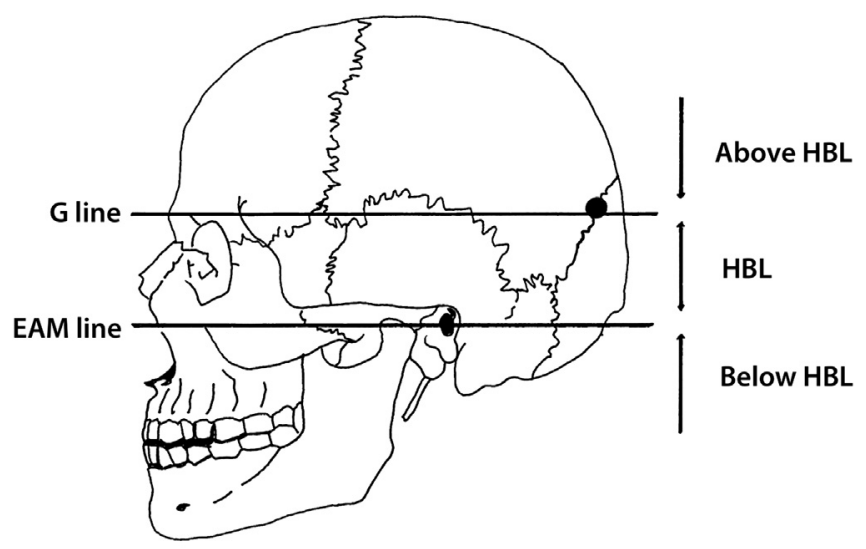

Fig. 5. Schematic representation of the point of impact of the second injury on lambdoidal suture and hat brim lines. (Drawings by Daniele Di Lorenzo).

healing; the uniform presence of stain from water, soil, or vegetation on broken and adjacent bone surfaces; the presence of greenstick fractures, incomplete fractures, spiral fractures, and depressed and compressed fractures. ${ }^{21,30}$ Perimortem usually implies that the injury is directly associated with the cause of death. ${ }^{20}$

Postmortem injuries are those that have occurred after death and tend to be characterized by smaller fragments, nonuniform coloration of the fracture ends and the adjacent bone surface, especially light-colored edges. ${ }^{30}$ Postmortem modifications are usually related to environmental factors, animal scavenging and anthropic activities. $^{42,43}$

The lesion on right parietal of T173, judging by its characteristics, does not appear to have been caused by postmortem factors. One can infer that the lesion is the perimortem effect of a sharp object, probably wielded at high velocity. ${ }^{30}$ This projectile struck the head of T173 from left to right and from top to bottom, with an angle of $45^{\circ}$ when compared to a horizontal plane, causing a fracture (Fig. 7) and then piercing the bone. The trajectory of the projectile crosses some of the grooves of the right middle meningeal artery and veins (Fig. 8). It is known that a transection of the middle meningeal vessels causes an epidural hematoma, often a fatal

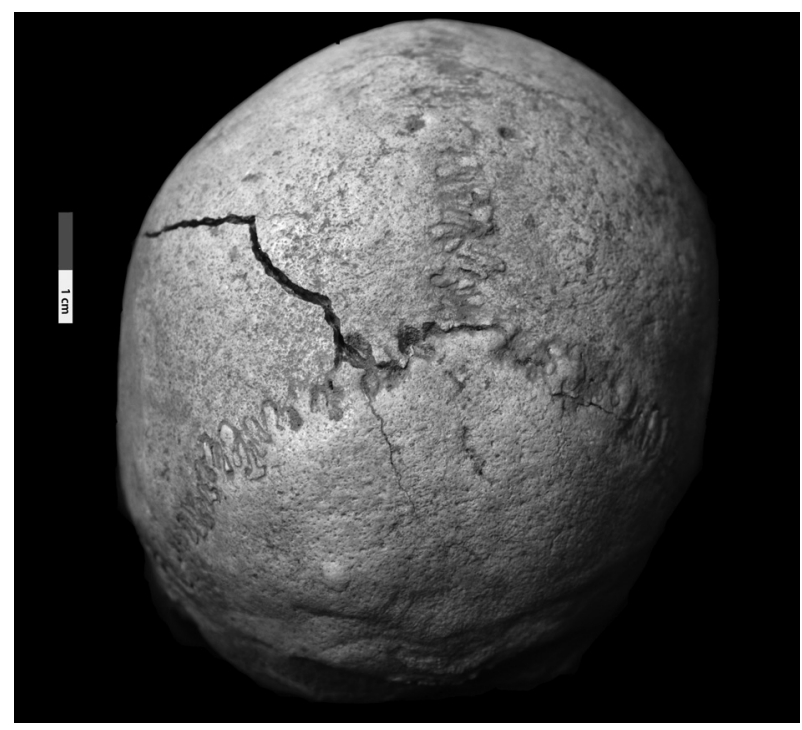

Fig. 6. Posterior view of the T173 skull. Fracture lines on left parietal near lambdoidal suture are visible. 


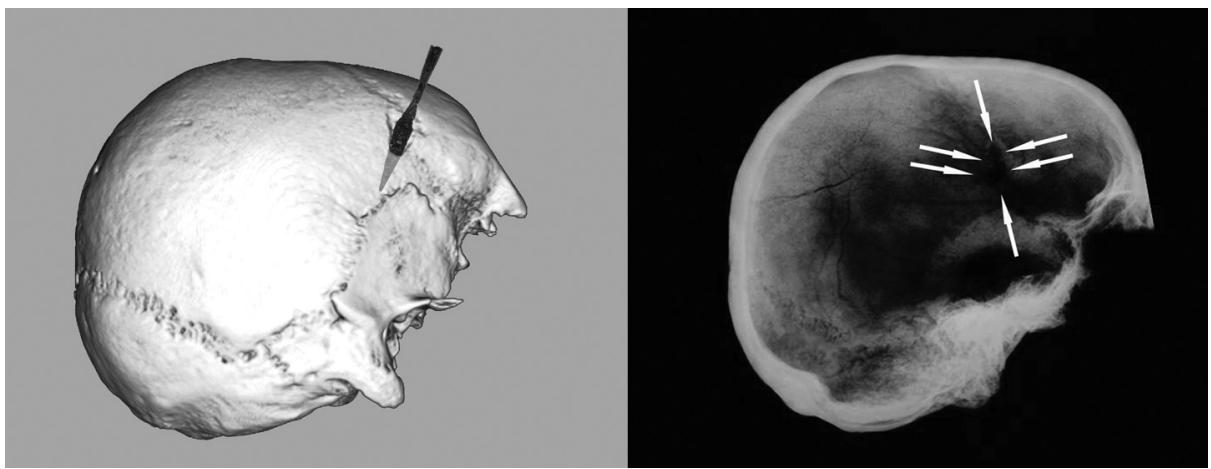

Fig. 7. Reconstruction of 3D trajectory of the projectile and lateral skull radiograph.

condition with the build up of blood trapped between the endocranial surface and the dura mater, in the 'Marchant Zone', i.e., the area from which the dura mater is readily detached. ${ }^{44}$ Because of the location of the middle meningeal vessels, the blood mass typically lies over the lateral hemisphere (temporal and/or parietal lobes).

Since the epidural hematoma is under pressure, it typically continues to grow unless evacuated. Classically, cranial trauma are associated with concussion and loss of consciousness; the individual may wake up after a lucid interval, only to lose consciousness again from brain stem distortion as a result of increased intracranial pressure. If the bleeding is very severe, there is no lucid interval. The individual has no time to awake from the concussion before compressive brain stem deterioration begins. ${ }^{45}$

Technically, the epidural hematoma could have been the cause of death of T173.

The pathological consequences of penetrating head wounds depend on the circumstances of the injury, including the properties of the weapon or missile, the energy of the impact, and the location and characteristics of the intracranial trajectory. ${ }^{46-48}$ Following the primary injury or impact, secondary injuries may develop. ${ }^{49,50}$ Secondary injury mechanisms are defined as pathological processes (traumatic and neurological) that occur after the time of the injury and adversely affect the ability of the brain to recover from the primary insult. ${ }^{51-53}$

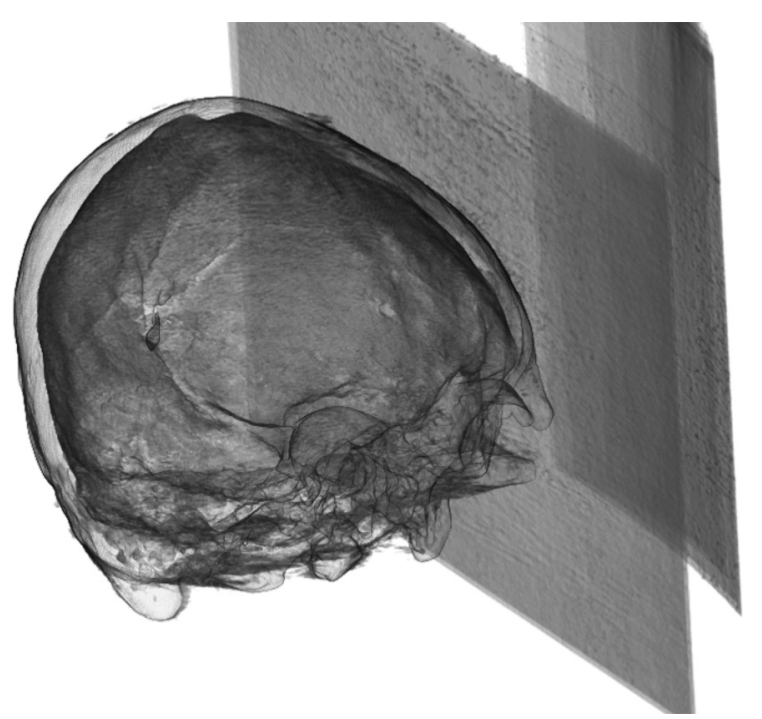

Fig. 8. T173: the perforation crosses some groves of middle meningeal artery.
Cranial computed tomography scanning (Fig. 9) clearly demonstrate the presence of splinter bone attached to the fracture margins confirming that the lesion was made on 'fresh' bone, ${ }^{21}$ and excludes the possibility that the lesion was caused a long time after death on dry bone by taphonomic factors. The characteristics and position of the lesion on the right parietal, the absence of a bony reaction on the margins of the perforation, and the presence of internal bevelling, all seem to indicate a perimortem trauma, occurring immediately before death (possibly the cause of death) or immediately after death.

In addition, the use of reconstructed 3D CT imaging allowed us to examine the endocranial surface without jeopardizing the integrity of the sample. For the lesion described in the right parietal bone we observed the presence of plastic response and hinging (Fig. 10a), typically associated with perimortem fractures. This result is consistent with the findings of macroscopic visual analysis.

The cause of the various fracture patterns lies in the changing biomechanical properties of the bone after death. ${ }^{30}$ Fresh or living bone contains fluid-filled vessels, grease and collagen fibers, which make it significantly more pliable and more resistant to tensile forces than dry bone. In consequence, fresh bones are likely to splinter with fragments tending to remain attached to one another, and with fractures producing irregular edges. After the death, on the other hand, the bone becomes harder and more brittle with time, and as a result shatters into small, more regular fragments. ${ }^{35,54}$

However, the bones retain 'fresh' properties for a considerable time after death. ${ }^{21,55,56}$ Therefore caution should be exercised when determining the timing of fractures. There are some analytical methods for studying the timing of a bone fracture of the postcranial skeleton, ${ }^{57,58}$ but no reference is available for the skull. In any case, the timing of injuries can be determined in a probabilistic manner. ${ }^{4}$

The lesion on the left parietal bone shows a pattern characteristic of a blunt force trauma, with radiating fracture lines from the point where the skull was struck. ${ }^{59}$ The 3D CT reconstruction of the cranium reveals a smooth preponderant texture and a regular outline (Fig. 10b). The lines of the fracture that radiate from the point of impact are not associated with plastic deformation of the skull and were probably produced at the same time as the trauma.

The features of the left parietal injury indicate that they were caused by a fall or a blow.

Distinguishing between falls and blows in blunt head trauma is a common and difficult problem in both forensic anthropology and bioarchaeology studies. ${ }^{5}$

Several authors ${ }^{59-65}$ have suggested methods for the discrimination of falls and blows, comprising three main indicators: the hat brim line rule, the side lateralization of fractures, and the number of 


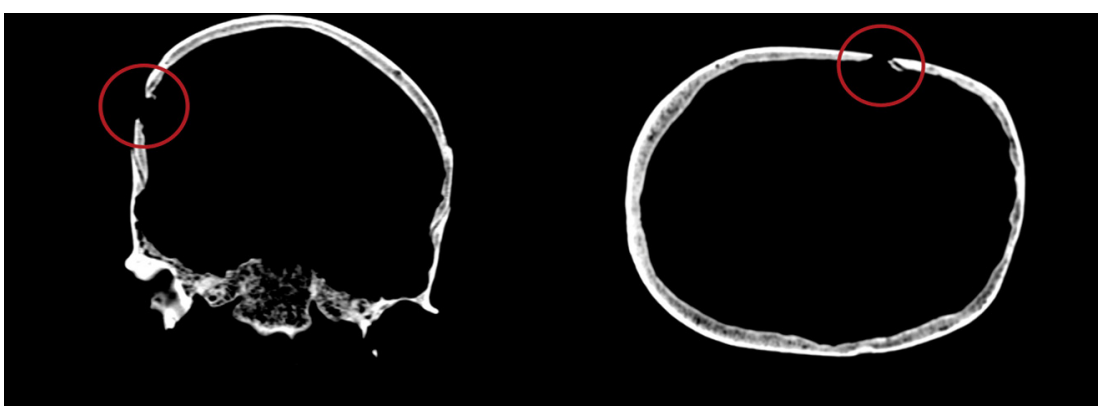

Fig. 9. CT scan of the skull shows the presence of splinter bone attached to the fracture margins.

lacerations. In the present study, we used the definition proposed previously by Kremer et al. ${ }^{5}$ : HBL corresponds to the area located between two lines parallel to a line inspired by the Frankfort horizontal plane (horizontal plane passing through right and left portion and the left orbitale), with the superior margin passing through the glabella ( $\mathrm{G}$ line) and the inferior margin passing through the center of the external auditory meatus (EAM line).

We could hypothesize that T173 was first struck on the right parietal bone by a sharp object with high kinetic energy. Taking into account the form of the injury and angle of the impact, an arrow is the object most likely to have caused this lesion. ${ }^{66}$

After this impact, T173 fell on the opposite side, hitting his head against a hard surface, thus suffering the fracture on the left parietal bone. Despite the severity of this wound, it cannot be assumed to be the cause of death. ${ }^{67,68}$

Nevertheless, this trauma could have caused a concussive cerebral lesion. Concussion is a state of diffuse cerebral dysfunction related to a shearing effect. Rapid displacement of the head, in either acceleration or deceleration injuries, causes a swirling of the cerebrum within the cranium and shearing forces play most markedly at the junctions between brain tissues of different densities.

The pattern of the cranial trauma on the right parietal bone of T173 has been observed in numerous other osteological samples from the Mediterranean area dating back to the Roman period. ${ }^{38,69}$

The association between Roman Imperial expansion and high levels of interpersonal violence has been documented. ${ }^{70,71}$

\section{Conclusion}

The analysis of the morphological characteristics of the lesions on the skull of T173, lead us to conclude that they were produced at or near the time of death; moreover, we can formulate a hypotheses about the manner in which they were inflicted.

We suggest that the lesion described in the right parietal bone was the result of an impact by a projectile, probably an arrowhead, which struck the individual from left and top; the trajectory crosses some of the grooves of the middle meningeal vessels and this resulted in a fatal intracranial hemorrhage. It is also plausible that the fragments of inner table, resulting from the impact, provoked a tearing of the vessels.

The fracture on the left parietal bone is a possible consequence of a fall, following the arrowhead trauma on the right side.

The application of bone fracture physics used by forensic experts, in particular physics related to sharp weapons and blunt trauma, could be of great benefit to archaeological interpretations of trauma. Unfortunately, the 'crime scene' in the archaeological context cannot be correctly evaluated because of the absence of the weapon and other records related to the circumstances of the individual's death. Also, in the forensic field elements may be missing which prevent an accurate reconstruction of the events leading up to the subject's death.

It is not possible to identify, with certainty, the weapon used to cause the lesion in T173, whether it be an arrow, as we suggest, or some other type of sharp object. However, there were only a few types of offensive sharp tools commonly used in the 1st century. This report enables us to supplement existing literature on similar cases, from which, only a broad comparison can lead to more certain interpretations.

\section{Ethical approval}

None declared.

\section{Authors' contributions}

A.D.M. and L.S. structured the research. G.C. critically revised the medical content. A.D.M., G.C., R.M. and L.S. analyzed the data and wrote the paper.

\section{Funding}

The research was funded on Fondi di Ateneo - attributed to L.S.

\section{Conflict of interest}

We hereby declare that there is no conflict of interest of the authors.
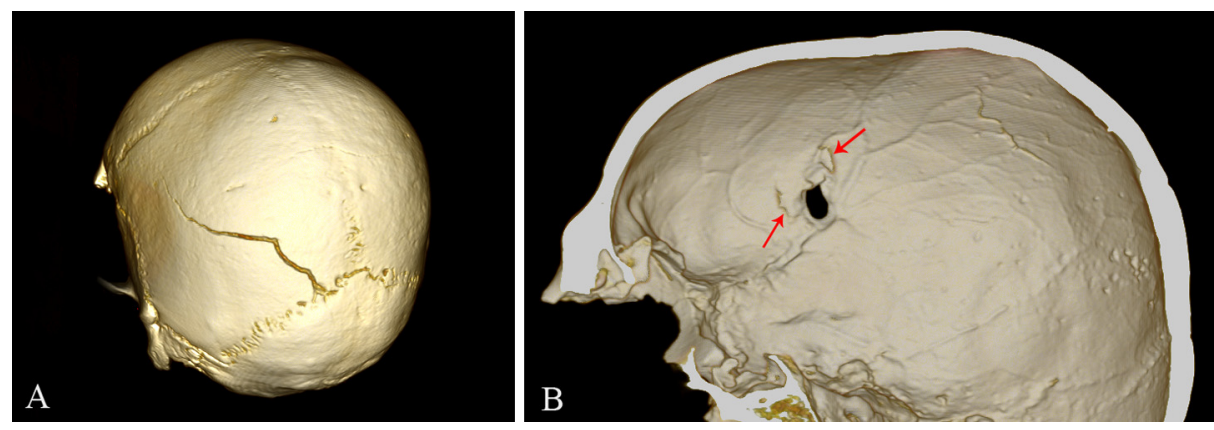

Fig. 10. 3D CT reconstruction images depicting the plastic response and hinging (a); smooth preponderant texture and regular outline (b). 


\section{References}

1. Finley MI. History of ancient Sicily. Roma: Ed. Laterza; 2009.

2. Bacci MG, Tigano G. Da Zancle a MessinaIn Un percorso archeologico attraverso gli scavi. Messina: Ed. Sicania; 2003.

3. Berryman HE, Haun SJ. Applying forensic techniques to interpret cranial fracture patterns in an archaeological specimen. Int I Osteoarchaeol 1996:6:2-9.

4. Jordana F, Colat-Parros J, Bénézech M. Diagnosis of skull fractures according to postmortem interval: an experimental approach in a porcine model. J Forensic Sci 2013;58:156-62.

5. Kremer C, Racette S, Dionne C-A, Sauvageau A. Discrimination of falls and blows in blunt head trauma: systematic study of the hat brim line rule in relation to skull fractures. J Forensic Sci 2008;53:716-9.

6. Aufderheide AC, Rodríguez-Martín C. The Cambridge encyclopedia of human paleopathology. Cambridge: Cambridge University Press; 1998.

7. Ortner J. Identification of pathological conditions in human skeletal remains. 2nd ed. San Diego: Academic Press; 2003.

8. Walker PL. A bioarchaeological perspective on the history of violence. Annu Rev Anthropol 2001;30:573-96.

9. Djurić MP, Roberts CA, Rakočcević ZB, Djonić DD, Lečsić AR. Fractures in late medieval skeletal populations from Serbia. Am J Phys Anthropol 2006;130:167-78.

10. Roksandic M, Djurić M, Rakošević Z, Seguin K. Interpersonal violence at Lepenski Vir Mesolithic/Neolithic complex of the iron Gates gorge (SerbiaRomania). Am J Phys Anthropol 2006;129:339-48.

11. Roksandic M, Wood C, Vlak D. Death in the line of duty: late medieval burials at the site of Lepenski Vir, Serbia. Int J Osteoarchaeol 2007;17:635-42.

12. Paine RR, Mancinelli D, Ruggieri M, Coppa A. Cranial trauma in iron age Samnite agriculturists, Alfedena, Italy: implications for biocultural and economic stress. Am J Phys Anthropol 2007;132:48-58.

13. Tung TA. Trauma and violence in the War Empire of the Peruvian Andes: warfare, raids and ritual fights. Am J Phys Anthropol 2007;133:941-56.

14. Jiménez-Brobeil SA, du Souich P, Al Oumaoui I. Possible relationship of cranial traumatic injuries with violence in the south-east Iberian Peninsula from the Neolithic to the Bronze Age. Am J Phys Anthropol 2009;140:465-75.

15. Jordana X, Galte I, Turbat T, Batsukh D, Garcý C, Isidro A, et al. The warriors of the steppes: osteological evidence of warfare and violence from Pazyryk tumuli in the Mongolian Altai. J Archaeol Sci 2009;36:1319-27.

16. Standen VG, Arriaza BG, Santoro CM, Romero Á, Rothammer F. Perimortem trauma in the Atacama desert and social violence during the Late Formative Period (2500-1700 years BP). Int J Osteoarchaeol 2010;20:693-707.

17. Rubini M, Zaio P. Warriors from the East. Skeletal evidence of warfare from a Lombard-Avar cemetery in central Italy (Campochiaro, Molise, 6th-8th century AD). J Archaeol Sci 2011;38:1551-9.

18. Erdal ÖD. A possible massacre at early Bronze age Titriş Höyük, Anatolia. Int J Osteoarchaeol 2012;22:1-21.

19. Ubelaker DH, Adams BJ. Differentiation of perimortem and postmortem trauma using taphonomic indicators. J Forensic Sci 1995;40:509-12.

20. Sauer $N$. The timing of injuries and manner of death: distinguishing among antemortem, perimortem and postmortem trauma. In: Reichs KJ, Bass WM, editors. Forensic osteology. Springfield: Charles Thomas; 1998. p. 321-32.

21. Wieberg DAM, Wescott DJ. Estimating the timing of long bone fractures: correlation between the postmortem interval, bone moisture content, and blunt force trauma fracture characteristics. I Forensic Sci 2008;53:1028-34.

22. Fleming-Farrell D, Michailidis K, Karantanas A, Roberts N, Kranioti EF. Virtual assessment of perimortem and postmortem blunt force cranial trauma. Forensic Sci Int 2013. http://dx.doi.org/10.1016/i.forsciint.2013.03.032.

23. Ruhli FJ, Lanz C, Ulrich-Bochsler S, Alt KW. State-of-the-art imaging in palaeopathology: the value of multislice computed tomography in visualizing doubtful cranial lesions. Int J Osteoarchaeol 2002;12:372-9.

24. Katz D, Suchey JM. Age determination of the male os pubis. Am J Phys Anthropol 1986;69:427-35.

25. Işcan MY, Loth SR, Wright RK. Metamorphosis at the sternal rib end: a new method to estimate age at death in white males. Am J Phys Anthropol 1984;65: $147-56$.

26. Buckberry JL, Chamberlain AT. Age estimation from the auricular surface of the ilium: a revised method. Am J Phys Anthropol 2002;119:231-9.

27. Murail P, Bruzek J, Houet F, Cunha E. DSP: a tool for probabilistic sex diagnosis using worldwide variability in hip bone measurements. BMSAP 2005;17:167-76.

28. Maples WR. Trauma analysis by the forensic anthropologist. In: Reichs KJ, editor. Forensic osteology: advances in the identification of human remains 1986. p. 218-28. Springfield.

29. Merbs CF. Trauma. In: Iscan MY, Kennedy KAR, editors. Reconstruction of life from the skeleton. New York: Wiley-Liss; 1989. p. 23-40.

30. Lovell NC. Trauma analysis in paleopathology. Yearb Phys Anthropol 1997; 40: 139-70.

31. Hu H. Multi-slice helical CT: scan and reconstruction. Med Phys 1999;26:5-18.

32. Hu H, He HD, Foley WD, Fox SH. Four multidetector-row helical CT: image quality and volume coverage speed. Radiology 2000;215:55-62.

33. Spitz WU. Spitz and Fisher's medicolegal investigation of death: guidelines for the application of pathology to crime investigation. Springfield: Charles C Thomas 1992.

34. Lewis JE. Identifying sword marks on bone: criteria for distinguishing between cut marks made by different classes of bladed weapon. J Archaeol Sci 2008;35: 2001-8.
35. Kanz F, Grossschmidt K. Head injuries of Roman gladiators. Forensic Sci Int 2006:160:207-16.

36. Reichs KJ. Forensic osteology: advances in the identification of human remains. Springfield: Charles C Thomas; 1998.

37. Bauer M, Patzelt D. Intracranial stab injuries: case report and case study. Forensic Sci Int 2002:129:122-7.

38. Erfan M, El-Sawaf A, Al-Tohamy Soliman M, El-Din AS, Kandeel WA, El-Shafy El-Banna RA, Azab A. Cranial trauma in Ancient Egyptians from the Bahariyah Oasis, Greco-Roman period. Res J Med Med Sci 4 2009:78-84.

39. Walker PL. Cranial injuries as evidence of violence in prehistoric southern California. Am J Phys Anthropol 1989;80:313-23.

40. Kaufman MH, Whitaker D, McTavish J. Differential diagnosis of holes in the calvarium: application of modern clinical data to palaeopathology. I Archaeol Sci 1997;24:193-218.

41. Nagaoka T. Cranial traumatic injuries caused by weapons in Tokugawa Japan. Int J Osteoarchaeol 2012:22:138-44

42. Quatrehomme GMY, Iscan MY. Postmortem skeletal lesions. Forensic Sci Int 1997;89:155-65.

43. Calce S, Rogers T. Taphonomic changes to blunt force trauma: a preliminary study. J Forensic Sci 2007;52:1-9.

44. Jennett B, Lindsay K. In: An introduction to neurosurgery. 5th ed. Oxford: Butterworth- Heinemann; 1994.

45. Lindsay KW, Bone I, Callander R. In: Neurology and neurosurgery illustrated. 2nd ed. New York: Churchill Livingstone; 1991.

46. Grahm TW, Williams Jr FC, Harrington T, Spetzler RF. Civilian gunshot wounds to the head: a prospective study. Neurosurgery 1990;27:696-700.

47. Siccardi D, Cavaliere R, Pau A, Lubinu F, Turtas S, Viale GL. Penetrating craniocerebral missile injuries in civilians: a retrospective analysis of 314 cases. Surg Neurol 1991;35:455-60.

48. Ardill W, Gidado S. Penetrating head wound: a remarkable case. Surg Neurol 2003;60:120-3.

49. Feldman Z, Narayan RK, Robertson CS. Secondary insults associated with severe closed head injury. Contemp Neurosurg 1992;14:1-8.

50. Cosar A, Gonul E, Kurt E, Gönül M, Tașar M, Yetișer S. Craniocerebral gunshot wounds: results of less aggressive surgery and complications. Minim Invasive Neurosurg 2005;48:113-8.

51. Aarabi B. Causes of infections in penetrating head wounds in the Iran-Iraq War. Neurosurgery 1989;25:923-6.

52. Tudor M, Tudor L, Tudor KI. Complications of missile craniocerebral injuries during the Croatian Homeland War. Mil Med 2005;170:422-6.

53. Cox MW, Whittaker DR, Martinez C, Fox CJ, Feuerstein IM, Gillespie DL. Traumatic pseudoaneurysms of the head and neck: early endovascular intervention. J Vasc Surg 2007;46:1227-33.

54. Evans FG. Mechanical properties of bone. Springfield, IL: Charles C. Thomas: 1973.

55. Fitzgerald ER. Dynamic mechanical measurements during the life to death transition in animal tissues. Biorheology 1975;12:397-408.

56. Galloway A. The biomechanics of fracture production. In: Galloway A, editor Broken bones: anthropological analysis of blunt force trauma. Springfield, IL: Charles C. Thomas; 1999. p. 35-62.

57. Villa P, Mahieu E. Breakage patterns of human long bones. J Hum Evol 1991;21: 27-48.

58. Boulestin B. Approche taphonomique des restes humainsIn Le cas des Mésolithiques de la grotte des Perrats et le problème du cannibalisme en préhistoire récente européenne. Oxford: Archeopress; 1999.

59. Kroman A, Kress TA, Porta D. Fracture propagation in the human cranium: a retesting of popular theories. Clin Anat 2011;24:309-18.

60. Knight B. Forensic pathology. Oxford: Oxford University Press; 1991.

61. Galloway A. The circumstances of blunt force trauma. In: Galloway A, editor. Broken bones anthropological analysis of blunt force trauma. Springfield: Charles C. Thomas; 1999. p. 224-54.

62. Ehrlich E, Maxeiner H. External injury marks (wound) on the head in different types of blunt trauma in an autopsy series. Med Law 2002;2:773-82.

63. Spitz WU. Blunt force injury. In: Spitz WU, Spitz DJ, editors. Spitz and Fisher's medicolegal investigation of death: guidelines for the application of pathology to crime investigation. 4th ed. Springfield IL: Charles C. Thomas; 2006. p. 199251.

64. Kremer C, Sauvageau A. Discrimination of falls and blows in blunt head trauma: assessment of predictability through combined criteria. J Forensic Sci 2009;54: 923-6.

65. Guyomarc'h P, Campagna-Vaillancourt M, Kremer C, Sauvageau A. Discrimination of falls and blows in blunt head trauma: a multi-criteria approach. J Forensic Sci 2010;55:423-7.

66. Southern P. The Roman army: a social and institutional history. Oxford: Oxford University Press; 2007.

67. Venkatesh VT, Kumar MV, Jagannatha SR, Radhika RH, Pushpalatha K. Pattern of skeletal injuries in cases of falls from a height. Med Sci Law 2007;47:330-4.

68. Preuss J, Padosch SA, Dettmeyer R, Driever F, Lignitz E, Madea B. Injuries in fatal cases of falls downstairs. Forensic Sci Int 2004:14:121-6.

69. Novak M, Slaus M. Bone traumas in late antique populations from Croatia. Coll Antropol 2010;4:1239-48.

70. Harris WV. War and imperialism in Republican Rome, 327-70 B.C. Oxford: Oxford University Press; 1979.

71. Rich J, Shipley G. War and society in the Roman world. London: Routledge; 1993. 